\title{
Development of Child Worksheets Based on the Story as Subtheme "My Body" to Improve Students' Speaking Abilities at Al-Ikhlas Early Childhood Education and Development (ECED) Medan Amplas
}

\author{
Saftian Cahyadi Hasibuan ${ }^{1}$, Sri Milfayetty ${ }^{2}$, R. Mursyid ${ }^{2}$ \\ ${ }^{1}$ Master Student in State University of Medan (Unimed), Medan, Indonesia \\ ${ }^{2}$ Lecturer in State University of Medan (Unimed), Medan, Indonesia \\ saftiancahyadi@gmail.com
}

\begin{abstract}
Story as Subtheme "My Body" to Improve Students' Speaking Abilities at Al-Ikhlas Early Childhood Education and Development (ECED) Medan Amplas. this research is included as a Developmental Research. In this study developed in the form of learning tools and instruments needed. This research was conducted at Al-Ikhlas Early Childhood Education and Development (ECED) Medan Amplas even semester in 2018/2019 academic year. Based on the results of the assessment of linguists at the first meeting, a score of 40 was obtained with a percentage of $71 \%$ and according to valid qualifications. in the second meeting the total score was 53 with a percentage of $95 \%$ or according to qualifications, it meant that Child Worksheet was based on a story that no longer needed revision.
\end{abstract}

Keywords: development of child worksheets based; Speaking Abilities; Early Childhood Education

\section{Introduction}

Speaking is the ability will not develop if not trained continuously. Therefore, the speaking ability of children will not be mastered properly without being trained routinely. If it is always trained, the ability to speak will certainly be better. Otherwise, if they are shy, doubtful, or afraid of wrong in practicing speaking, surely it is getting away from mastery. The speaking ability is more easily developed if the child has the opportunity to communicate something naturally to others. During learning activities in kindergarten, teachers are expected to be able to create a variety of experiences that allow the right to develop speaking skills.

According to Jamaris (2003: 71) states that the readiness of children to interact with adults means the development of their understanding of the rules and functions of language with adults will provide a relationship with the concept, in this case the child will get the experience of learning about language from the environment around him with imitating the language style of the adults around him too. Therefore language skills in early childhood and after adolescence will greatly depend on the acquisition of language skills obtained from now on, it will result in success in language in the future.

The speaking ability of Al-Ikhlas Kindergarten is still lacking. This was proven in the previous academic year many children were still unable to speak fluently. In the kindergarten teacher guidelines stated that in carrying out the coaching and development of language in kindergarten, students should prepare the principles by providing the best possible opportunities for children in developing language and in maintaining order, the child's spontaneity should not be suppressed and should be given in an atmosphere of intimacy between the teacher and students, and meet the requirements taken from the child's environment, according to the age level and level of child development so that aspects of child development can be achieved optimally. 
The problems that occur at this time are not all teachers in existing kindergartens, are less able to tell stories well, the methods used are also sometimes too monotonous, so they don't attract students' attention in understanding the contents of existing stories, in this case students often lack the attention of the teacher in expressing a feeling or idea, so that the language abilities possessed by children do not develop optimally, in addition it is not uncommon for the teacher to focus more on reading and writing and numeracy skills activities, arguing that reading and writing and numeracy skills are wrong one demand for further education, namely when early childhood enters elementary school, so that early childhood are less able to express feelings or ideas when answering questions from the teacher and do not understand the information conveyed by the teacher, vocabulary is still minimal, and children are very difficult to assemble letters even some letters are still misread by children because children still do not understand letters.

At an early age children should be fluent and clear in expressing their desires without fear. Good speaking skills can be mastered by children aged 5-6 years, because it makes it easier in the learning process. Good language skills can also help children communicate smoothly with those around them.

But the reality of children in Al-Ikhlas Early Childhood Education and Development (ECED) has not yet mastered the daily vocabulary that is heard, explained or conveyed by their teachers and peers. This can be seen from the ability to speak everyday children at school and their own environment. The low language ability of children is thought to be caused by unattractive learning media, inadequate facilities and infrastructure that causes children to feel bored. For this reason, education in Al-Ikhlas Early Childhood Education and Development (ECED) is demanded to be able to develop children's language through fun games.

\section{Review of Literature}

\subsection{Speaking Ability}

The ability to speak is the ability of children to communicate verbally with others. This ability provides an overview of the ability of children to compile various vocabulary that has been mastered into a series of structured talks (Ministry of National Education, 2005: 15). Meanwhile, according to Dhieni (2007: 36) that the development of speech in children begins with the child murmuring and parroting, the development of speech provides the greatest contribution to the development of writing in children. Gradually the child's ability to increase, starting from expressing the sound alone, so that expressing it with communication.

In early childhood, the most common and effective language ability is speaking. This is consistent with the general characteristics of children's language skills at that age. These characteristics include the ability of children to be able to speak properly, carry out three verbal commands in sequence correctly; listen and retell simple stories in an easy to understand sequence; mention their name, gender and age; use conjunctions like: and, because, but, use question words like how, what, why, when, compare two things, understand the concept of reciprocity, arrange sentences, say more than three sentences, and recognize simple writing (Dhieni 2005: 39).

Wibowo (2011: 54) speaks in essence as a process of communication, because in it messages occur from one source to another. Speaking is the most important communication tool in groups. Children learn how to speak well in communicating with others. Increased 
vocabulary from various sources causes more vocabulary owned. Children begin to realize that meaningful communication cannot be achieved if the child does not understand what is said by others.

\subsection{Speaking Method}

The method is a way that in its function is a tool to achieve the objectives of the activity. Therefore, in choosing a method that will be used in a children's activity program in kindergarten must have a strong reason and factors that support the selection of the method.

According to Hibanah (2002: 8) a story is a verbal description of something. Through storytelling, children are invited to communicate, fantasize, fantasize and develop their cognition. Storytelling is a stimulant that can arouse children mentally involved. Through stories, children's mental activity can soar, wander beyond the content of the story itself. Thus through stories, intelligence, emotional children increasingly focused. Storytelling is an activity carried out by someone to convey a message, information or a mere fairy tale, which is usually done verbally or in writing (Gunarti, 2008: 5).

\subsection{Child Worksheet}

In early childhood education, especially in kindergarten, Student Worksheet is better known as Child Worksheet, which is a child worksheet. Child Worksheet will assist the learning process using a constructivist approach, because children will be more active and independent (Pratiwi and Mustaji. 2016: 25). In Child Worksheet, students will get material, summaries, and assignments related to the material. In addition, students can also find structured direction for understanding the material provided. At the same time, students are given material and assignments related to the material (Prastowo. 2011: 204).

According to Soekamto (2010: 47) Children's Worksheets are sheets containing guidelines for students to carry out activities so that students acquire knowledge and skills that need to be mastered. Meanwhile according to Akhyar and Mustain Child Worksheet is teaching material that is already known in such a way that students are expected to be able to learn the teaching material.

Child Worksheet is one of the important teaching materials for achieving success in learning. Eli (2009) states that a child worksheet is a teaching material that has been packaged in such a way that students are expected to be able to study the teaching material independently. Child Worksheet is also a learning media, because it can be used together with learning resources or other learning media. Damayanti (2013) states that Child Worksheet is the source of learning and the learning media, depends on the learning activities that are designed.

\section{Research Method}

Based on the problem of the study and the stated research objectives, this research is included as a Developmental Research. In this study developed in the form of learning tools and instruments needed. According Sugiyono (2011: 407) Research and development methods are research methods used to produce certain products, and test the effectiveness of these products. To be able to produce certain products that are used research that is needs analysis and to test the effectiveness of the product so that it can function in the wider community, then research is needed to test the effectiveness of these products. So research and development are 
longitudinal. Development research is research that produces products, so the method used is research and development methods. The final product is evaluated based on the specified product quality aspects.

This research was conducted at Al-Ikhlas Early Childhood Education and Development (ECED) Medan Amplas even semester in 2018/2019 academic year. The reason researchers chose this school, was because similar research had never been carried out at the school. Furthermore, learning has so far been conventional with learning dominated by teachers, passive students and always waiting for the teacher's commands, student interaction with students and teachers rarely occurs.

\section{Discussion}

The results of the assessment of learning language experts on the development of a story-based Child Worksheet submitted through a questionnaire method with a questionnaire instrument are presented descriptively as follows.

Tabel 1. Language Validation Results

\begin{tabular}{|c|c|c|c|c|}
\hline \multirow{2}{*}{$\begin{array}{c}\text { Assessment } \\
\text { Aspects }\end{array}$} & \multirow[t]{2}{*}{ Rating Indicator } & \multicolumn{2}{|c|}{ Meeting } & \multirow[t]{2}{*}{ Value } \\
\hline & & 1 & 2 & \\
\hline \multirow{6}{*}{$\begin{array}{l}\text { The aspect of } \\
\text { Using } \\
\text { Language }\end{array}$} & 1. The stangness of structure & 2 & 4 & Very well \\
\hline & 2. The effectivness of sentences & 3 & 4 & Very well \\
\hline & $\begin{array}{l}\text { 3. The conspicuousness language of } \\
\text { subject }\end{array}$ & 3 & 3 & well \\
\hline & 4. The conspicuousness of sentence & 3 & 3 & well \\
\hline & 5. The interensting of language style & 3 & 4 & Very well \\
\hline & $\begin{array}{l}\text { 6. Using the contextual and meaning } \\
\text { indonesia language well and rightly }\end{array}$ & 3 & 3 & Well \\
\hline \multirow{5}{*}{$\begin{array}{l}\text { Aspect of } \\
\text { acurracy } \\
\text { language }\end{array}$} & 7. The conspicuousness of alphabets & 3 & 4 & Very well \\
\hline & 8. Using symbol & 3 & 4 & Very well \\
\hline & $\begin{array}{l}\text { 9. The conspicuousness of using } \\
\text { command sentences }\end{array}$ & 3 & 4 & Very well \\
\hline & $\begin{array}{l}\text { 10. Used language simply, righly and } \\
\text { clearly }\end{array}$ & 3 & 4 & Very well \\
\hline & $\begin{array}{l}\text { 11. Using spelling that is corrected by } \\
\text { EYD }\end{array}$ & 3 & 4 & Very well \\
\hline $\begin{array}{l}\text { Aspect of } \\
\text { acurracy }\end{array}$ & $\begin{array}{l}\text { 12. adapted Language to the stages of } \\
\text { student development }\end{array}$ & 2 & 4 & Very well \\
\hline
\end{tabular}




\begin{tabular}{|c|c|c|c|c|}
\cline { 2 - 5 } $\begin{array}{l}\text { development } \\
\text { tudent }\end{array}$ & $\begin{array}{l}\text { 13. Language will develop imagination } \\
\text { and creativity }\end{array}$ & 3 & 4 & Very well \\
\cline { 2 - 5 } $\begin{array}{l}\text { 14. Language is easy to be undertood } \\
\text { by students }\end{array}$ & 3 & 4 & Very well \\
\hline Result & $\mathbf{4 0}$ & $\mathbf{5 3}$ & \\
\hline \multicolumn{1}{|c}{$\%$} & $\mathbf{7 1}$ & $\mathbf{9 5}$ & Very well \\
\hline
\end{tabular}

Conversion of numbers specified in the questionnaire of expert, uses the following conditions: SB (Very Good = 4), B (Good = 3), CB (Good Enough = 2), TB $($ Not Good = 1) .Based on the results of the assessment of linguists at the first meeting, a score of 40 was obtained with a percentage of $71 \%$ and according to valid qualifications. However, in the valid category, researchers corrected several revisions of the language validator. Next, the researchers revised the product and validated it back to the experts. And in the second meeting the total score was 53 with a percentage of $95 \%$ or according to qualifications, it meant that Child Worksheet was based on a story that no longer needed revision.

In addition to providing grades, experts also provide comments and suggestions related to language in Child Worksheet based on the story at each meeting. The following is a description of things that need to be revised in the Child Worksheet language provided by the material experts at each meeting.

Tabel 2. Revision List of Linguists at Each Meeting

\begin{tabular}{|c|c|c|}
\hline Aspect of Validation & $1^{\text {st }}$ Meeting & $2^{\text {nd }}$ Meeting \\
\hline Language & $\begin{array}{l}\text { 1. Pay attention to } \\
\text { punctuation used } \\
\text { according to language } \\
\text { rule. } \\
\text { 2. Using language is } \\
\text { appropriate with the } \\
\text { child's development }\end{array}$ & $\begin{array}{l}\text { It need to be explained "the } \\
\text { definition of Geometry in } \\
\text { Indonesia language (KKBI) }\end{array}$ \\
\hline
\end{tabular}

All comments and suggestions given validator were taken into consideration in revising the story-based Child Worksheet that was developed. The final goal of this research is to produce teaching materials that are suitable for use. The final product produced in this study is Story-Based Child Worksheet

The process of developing teaching materials is begun with a material development plan that ultimately results in the design of teaching materials in the form of Child Worksheet Based Stories.

Based on the results of the analysis of teacher needs, it can be concluded that the development based on children story worksheets is indeed very much needed by teachers and children in the learning process. The results of an oral interview to the study teacher myself, stated that learning myself requires a child-based worksheet to support the learning process during the learning process in the classroom or outside the classroom because it is difficult to get effective learning media to deliver my Subtheme material in textbooks .

The choice of story base in developing children's worksheets aims to enable students to improve their ability to talk to others. With high speaking skills and clear articulation, students 
can convey their intentions, explain the causes and how to solve problems, choose problem solving strategies, find (discover) new methods, argue (reasoning), and take the right decisions.

Based on the results obtained from the discussion above, the story-based child worksheet is very relevant to the needs of teachers and students. Because the story-based child worksheets that have been developed have been adapted to the needs of students, based on children story worksheets are also presented with contextual material (linked to student life) and the storybased children worksheets that have been prepared are in accordance with the 2013 Curriculum.

The stages of development undertaken by researchers are (1) the stage of media selection, (2) the stage of format selection, (3) the initial design stage. After this stage is completed by the researcher, the preparation of the worksheet is done by the researcher, then the teaching material or Child Worksheet can be submitted to the expert to be validated.

Researchers determine three experts for the validation process of teaching materials that have been developed. Validated fields are material, language and learning media (presentation). After all the experts stated the teaching materials were valid and feasible to be used and tested.

This story-based Child Worksheet was developed with a view to optimizing children's speaking abilities. The story-based child worksheet that has been developed has fulfilled the requirements of learning appraisal tools for eligible PAUD students according to Zaman (2006: 7-8), which is in accordance with the applicable education program so that its creation will greatly assist the achievement of the objectives contained in the compiled educational program, pay attention to technical requirements in making story-based Child Worksheet such as, preparation of observation sheets, media selection, format selection, and initial design results.

This developmental research produced a story-based child worksheet that was appropriate to be used in learning assessment. Product eligibility is obtained by using a questionnaire instrument in which there is an assessment in terms of material, media and language. The validation results that have been obtained are described as follows:

1. The results of the expert validation of the material at the first meeting, obtained a total score of 43 with a percentage of $63 \%$ and are less valid qualifications, this means that in the material field still needs to be improved. Next the researchers revised the product and validated it back to the experts. And in the second meeting the total score was 51 with a percentage of $75 \%$ or in valid qualifications meaning that the story-based child worksheet no longer needed to be revised.

2. The results of the validation of the media experts at the first meeting of the story-based child worksheet design that was developed, obtained the percentage of assessment scores with a weighting of $56 \%$ on sufficient / moderate qualifications, so that the media of teaching materials developed needs to be revised. Next the researchers revised the product and validated it back to the experts. At the second meeting of the story-based child worksheet media that was developed, the percentage obtained for the assessment score with a weight of $75 \%$ was in good qualifications, so that the media for teaching materials developed did not need to be revised again.

3. The results of the assessment of linguists at the first meeting, obtained a total score of 40 with a percentage of $71 \%$ and are in valid qualifications. Even though it is in the valid category, the researcher corrects several revisions of the language validator. Next the researchers revised the product and validated it back to the experts. And at the second 
meeting the total score was 53 with a percentage of $95 \%$ or being in very valid qualifications meaning that the story-based child worksheet no longer needed to be revised.

Based on the results obtained from the series of stages of development of story-based child worksheet, it was declared effective to use.

\section{Conclusions}

The process of developing based on children story worksheet in Al-Ikhlas Early Childhood Education and Development (ECED) Medan Amplas goes through 4 stages namely; (1) Preparation of Tests (2) Media Selection (3) Format Selection (4) Results of initial design by making layouts by paying attention to color and composition and filling layouts with activities in the form of containing core competency mapping lbasic competencies $\backslash$ and indicators, and materials based on indicators.

The level of effectiveness of story-based child worksheet based on the results of this study shows that in the material aspect in the "Good" category by $75 \%$, in the media aspect also in the "Good" category by $75 \%$, and in the language aspect in the "Very Good" category by $94 \%$.

The results of the final observation of a child's speaking ability if the value of sig, $<0.05$ $(0.000<0.05)$ shows that the child's speaking ability that is taught by using a child's worksheet is higher than the ability to speak the child who is taught with textbooks that are commonly used by teachers.

\section{References}

Agustina, S. (2008). Mendongeng Sebagai Energi Bagi Anak. Jakarta: Rumah Ilmu Indonesia.

Akhadiah, S. (2008). Pembinaan Kemampuan Menulis Bahasa Indonesia.

Jakarta: Erlangga.

Aisyah, S, dkk. (2011). Perkembangan dan Konsep Dasar Pengembangan Anak Usia Dini. Jakarta : Universitas Terbuka.

Ashyar, R. (2012). Kreatif Mengembangkan Media Pembelajaran, Jakarta: Referensi Jakarta.

Agustiani. H. (2009). Psikologi Perkembangan.Bandung.: Aditama

Arsyad, R. (2013). Media Pembelajaran. Jakarta: PT Raja Grafindo Persada. Asfandiyar, A. Y. (2007). Cara Pintar Mendongeng. Mizan. Jakarta.

Bachir, B. S. (2005). Pengembangan Kegiatan Bercerita di Taman Kanak- Kanak dan Teknik dan Prosedurnya. Jakarta: Depdiknas.

Boltman, A, (2001). Children's Storytelling Technologies: Differences in Ellaboration and Recall. http://itiseer.1st.psu.edo/563253.html.

Bunanta, M. (2009). Buku, Dongeng, dan Minat Baca. Jakarta: Murti Bunanta Foundation.

Beaty. (2013). Observasi Perkembangan Anak usia Dini. Jakarta: Kencana.

Bennett, N. (2005). Teaching through play teachers thinking and classroom practice. (Terjemahan Nur Adi Trastria). USA: Open University press.

Depdiknas. (2006). Standar Kompetensi Lulusan untuk Satuan Pendidikan Dasar dan

Menengah. Jakarta: Direktorat Jenderal Pendidikan Dasar dan Menengah.

Depdiknas. (2007). Pedoman Pengembangan Bidang Seni di Taman Kanak-kanak. Jakarta. 
Depdiknas. (2007). Pedoman Pengembangan Fisik/Motorik di Taman Kanak-kanak. Jakarta. Diana. (2013). Pemanfaatan ICT Dalam Pembelajaran Matematika Bagi Anak Usia Dini. Tesis. Universitas Negeri Semarang.

Dimyanti, \& Mudjiono. (2009). Belajar dan Pembelajaran. Jakarta: Rineka Cipta.

Djamarah, B. S. (2011). Psikologi Belajar, Jakarta: PT. Rineka Cipta. Fauzi, L. (2008). Remaja dan Media Massa. Jakarta: Grasindo.

Damayanti, D. S. (2013). Pengembangan Lembar Kerja Siswa (LKS)

Dengan Pendekatan Inkuiri Terbimbing Untuk MengoptimaChild Worksheetn Kemampuan Berpikir Kritis Peserta Didik pada Materi Listrik Dinamis SMA Negeri 3 Purworejo kelas X

Daulay, S. (2008). Pemerolehan \& Pembelajaran Bahasa. Bandung: Cita Pustaka Media Perintis.

Dewi, R. (2005). Berbagai Masalah Anak Taman Kanak-Kanak. Jakarta: Depdiknas Dirjen Dikti.

Dhieni, dkk. (2005). Metode Pengembangan Bahasa. Jakarta: UT Press Djamarah, S. B. (2011). Psikologi Belajar. Jakarta: PT. Rineka Cipta

Gunarti.W, dkk. (2008). Metode Pengembangan Perilaku dan Kemampuan Dasar Anak Usia Dini. Jakarta: Universitas Terbuka.

Harahap. L. W dan Edy. S. (2017). "Development of Learning Media in Mathematics for Students with Special Needs". International Journal of Sciences: Basic and Applied Research (IJSBAR). Volume 33, No 3, pp 1-1.

Henniger, (2013). Teaching Young Children An Introduction FifthEdition, USA: Pearson. Hibama S. R. (2002). Konsep Dasar Pendidikan Anak Usia Dini. Yogyakarta: Galah

Idris, H. M. (2014). Meningkatkan Kecerdasan Anak Melalui Dongeng. Jakarta: Luxima Metro Media.

Inayah, R. (2015). Improving students' speaking skill trough storytelling technique. ELTIN journal.(3).(1).

Jamaris, M. (2003). Perkembangan Dan Pengembangan Anak Usia TK. Pedoman Bagi Orang Tua dan Guru. Program PAUD, PPS Universitas Negeri Jakarta.

Joyce, B., Weil, M. dan Calhoun, E. (2011), Models of Teaching, Eighth Edition, Boston New York San Francisco : Pearson Education, Inc.

Kurniasi, I dan Berlin S. (2014). Panduan Membuat Bahan Ajar Buku Teks Pelajaran Sesuai Dengan Kurikulum 2013. Surabaya: Kata Pena 